\title{
A new acid-tolerant nitrogen-fixing bacterium associated with sugarcane
}

\author{
VLADIMIR A. CAVALCANTE and J. DOBEREINER \\ EMBRAPA - Programa Nacional de Pesquisa em Biologia do Solo, Km 47, Seropédia, 23851, Rio de \\ Janeiro, Brazil
}

Key words: acetic acid bacteria, Acetobacter, Frateuria, Gluconobacter, $\mathrm{N}_{2}$ fixation, Saccharobacter, sugarcane

\begin{abstract}
During surveys of bacteria possibly responsible for $\mathrm{N}_{2}$ fixation in sugarcane, root and stem samples were collected in four sugarcane-growing regions in Brazil. A new microaerobic $\mathrm{N}_{2}$-fixing bacterium was isolated from most samples of washed roots and stems from all regions. Isolation procedures were based on semisolid diluted sugarcane juice medium followed by replication to $\mathrm{N}$-free $10 \%$ sugar medium acidified with acetic acid to $\mathrm{pH}$ 4.5. The new bacterium is an aerobic rod, motile by 1 to 3 lateral flagella, fixes $\mathrm{N}_{2}$ in semisolid media under air but not in liquid media except when a starter dose of $\mathrm{N}$ is added. It has no nitrate reductase and $\mathrm{N}_{2}$ fixation proceeds in the presence of $10 \mathrm{mM} \mathrm{NO} \mathrm{NO}_{3}^{-}$. Best growth occurs with high sucrose concentrations $(10 \%)$. Growth occurs up to $30 \%$ sucrose but not at $35 \%$. Acid is formed reaching a final pH of below 3.0. Growth and $\mathrm{N}_{2}$ fixation proceed at this acidity. Ethanol is used for growth and is "overoxidised" (oxidized to $\mathrm{CO}_{2}$ and $\mathrm{H}_{2} \mathrm{O}$ ). Acetic and lactic acids are also oxidized to $\mathrm{CO}_{2}$ and $\mathrm{H}_{2} \mathrm{O}$. Acids produced from glucose are consumed with precipitation of $\mathrm{CaCO}_{3}$. Dark brown colonies are formed on potato agar with $10 \%$ sugar and dark orange colonies on $\mathrm{N}$ poor agar $(20 \mathrm{mg}$ yeast extract per 1$)$ containing bromothymol blue. In view of the distinct characteristics which do not allow identification within either Frateuria, Gluconobacter, Acetobacter or any known $\mathrm{N}_{2}$-fixing bacterium a new genus and species are proposed and named Saccharobacter nitrocaptans.
\end{abstract}

\section{Introduction}

Sugarcane in Brazil is grown, not only for sugar, but in recent years it has become the basis for an ambitious fuel-alcohol project with more than 10 billion litres annually available for the replacement of fossil fuels. The success of such a project is invariably dependent on production systems with a positive energy balance as have been in use for decades in Brazil. Low input agriculture is typical for the traditionl North-East sugarcane areas but increased yields with continuing positive energy balances must rely on increased efficiency and or partial replacement of $\mathrm{N}$ fertilizers. Recently very promising results were obtained by $\mathrm{N}$ balance and ${ }^{15} \mathrm{~N}$ isotope dilution studies (Lima et al., 1987) indicating that substantial amounts of $\mathrm{N}_{2}$ can be fixed by certain sugarcane cultivars. Nevertheless no data are available yet as to the responsible $\mathrm{N}_{2}$ fixing bacteria.

The first observations on selective stimulation of $\mathrm{N}_{2}$-fixing bacteria in sugarcane were reported many years ago in Brazil (Dobereiner and Alvahydo, 1959; Dobereiner, 1961). While $95 \%$ of more than 100 sugarcane soil samples contained Beijerinckia, only $60 \%$ of soil samples collected under other crops contained the bacterium. Also in the sugarcane rhizosphere and on the root surface there were 20 to 50 times more Beijerinckia and 2 to 5 times less other microorganisms than in control soil (Dobereiner 1961). Attempts to assess nitrogen fixation by the $\mathrm{C}_{2} \mathrm{H}_{2}$ reduction method indicated that most nitrogenase activity occurred in the rhizosphere soil but not in roots (Dobereiner et al., 1972; Ruschel, 1979). Various methods have been used to identify other responsible diazotrophs 
(Rennie, 1981; Rennie et al., 1982) which seemed to yield almost exclusively Enterobacteriaceae isolated from the root surface. The two sugar-using Azospirillum spp, A. lipoferum and A. amazonense (unpublished observations from J Dobereiner) and a new Bacillus sp., B. azotofixans (Seldin et al., 1984) were isolated from sugarcane roots from various sites in Brazil and from Hawaii, and unidentified diazotrophs were found to be present within sugarcane cuttings which multiplied and became active only after the emergence of roots (Patriquin et al., 1980).

Here we report the occurrence of an entirely different new $\mathrm{N}_{2}$-fixing bacterium in sugarcane roots and stems collected in various regions in Brazil.

\section{Materials and methods}

Sugarcane roots and stems were collected in various sugarcane regions from several cultivars. More details of the origin of samples are summarized in Table 1. Roots and stems were washed in tap water, macerated in a blender and serial dilutions prepared in sugar solution $(5 \%$ cane sugar in $\mathrm{H}_{2} \mathrm{O}$ ) and inoculated into various enrichment media:

A. Semisolid LGI medium consisted of (quantities per litre): $\mathrm{K}_{2} \mathrm{HPO}_{4}, 0.2 \mathrm{~g} ; \mathrm{KH}_{2} \mathrm{PO}_{4}, 0.6 \mathrm{~g}$; $\mathrm{MgSO}_{4} \cdot 7 \mathrm{H}_{2} \mathrm{O}, 0.2 \mathrm{~g} ; \mathrm{CaCl}_{2} \cdot 2 \mathrm{H}_{2} \mathrm{O}, 0.02 \mathrm{~g} ; \mathrm{Na}_{2}-$ $\mathrm{MoO}_{4} \cdot 2 \mathrm{H}_{2} \mathrm{O}, 0.002 \mathrm{~g} ; \mathrm{FeCl}_{3} \cdot 6 \mathrm{H}_{2} \mathrm{O}, 0.01 \mathrm{~g}$; bro- mothymol blue $0.5 \%$ solution in $0.2 \mathrm{~N} \mathrm{KOH}, 5 \mathrm{ml}$, agar, $1.8 \mathrm{~g}$; crystallized cane sugar, $100 \mathrm{~g}$; final $\mathrm{pH}$ 6.0 .

B. Acetic LGI medium was acidified with acetic acid to pH 4.5 (Micales et al., 1985) and the agar concentration increased to $2.2 \mathrm{~g}$ per 1 .

C. Diluted cane juice medium contained $250 \mathrm{ml}$ of medium $A$ and $250 \mathrm{ml}$ of sugarcane juice complemented with $\mathrm{H}_{2} \mathrm{O}$ to 11 .

D. LGI medium plates used for isolation contained the same ingredients as medium $A$ but $0.02 \mathrm{~g}$ of Difco yeast extract and $15 \mathrm{~g}$ of agar were added.

E. Potato agar was prepared according to Dobereiner (1980) but malate was omitted and the sugar concentration increased to $100 \mathrm{~g}$ per 1 .

Vials with diluted cane juice medium usually showed nitrogenase activity $\left(\mathrm{C}_{2} \mathrm{H}_{2}\right.$ reduction $)$ from dilutions $10^{-2}$ to $10^{-6}$ or $10^{-7}$ after 3 to 7 days and characteristic growth patterns in nitrogenase positive vials were light coloured medium with whitish surface pellicles or growth throughout the medium with gas production. Such vials were replicated into semisolid LGI medium, or in later investigations, into acetic LGI medium and those showing the typical heavy orange-yellow surface pellicles on colourless medium were streated out on LGI plates. After 7 to 10 days typical dark orange colonies were transferred again into acetic LGI medium and then purified on potato agar plates.

With these methods isolates of the new bacterium were obtained from root samples of five cultivars collected from the sugarcane region of the

Table 1. Origin of strains of the new bacterium obtained from roots and stems of sugarcane in various regions in Brazil

\begin{tabular}{|c|c|c|c|c|}
\hline Region & State & Sample & $\begin{array}{l}\text { Number of } \\
\text { isolated } \\
\text { strains }^{\mathbf{a}}\end{array}$ & $\begin{array}{l}\text { Sugarcane } \\
\text { cultivars }\end{array}$ \\
\hline \multirow{3}{*}{$\begin{array}{l}\text { Traditional } \\
\text { sugarcane } \\
\text { areas in North } \\
\text { East Brazil }\end{array}$} & Alagoas & Washed roots & $5^{\mathrm{b}}$ & $\begin{array}{l}\text { RB } 724454, \text { RB } 72102, \text { RB } 70194 \\
\text { CO } 997, \text { CB } 45-3\end{array}$ \\
\hline & Pernambuco & Washed roots & 5 & CB 47-15, CR 51-22, CB 45-3 \\
\hline & & Washed stems & 5 & RB 12-954, SP 70-1143 \\
\hline \multirow{2}{*}{$\begin{array}{l}\text { New inten- } \\
\text { sively culti- } \\
\text { vated sugar } \\
\text { cane areas in }\end{array}$} & São Paulo & Washed roots & 5 & $\begin{array}{l}\text { SP } 701143, \text { CP } 4374, \text { CB } 4135 \\
\text { NA } 5779, \text { SP } 711406\end{array}$ \\
\hline & & Washed stems & 2 & \\
\hline $\begin{array}{l}\text { South East } \\
\text { Brazil }\end{array}$ & Minas Gerais & Washed roots & 1 & Native variety \\
\hline
\end{tabular}

a Many more isolates were obtained but only isolates from different samples were considered strains. All strains were identified by their characteristic growth patern in N-free semi-solid acetic LGI medium ( $\mathrm{pH} 4.5$ ) and by their dark orange-red colonies on LGI plates and brown colonies on potato medium with $10 \%$ sugar.

b Five samples, one from each of 5 cultivars were collected except Minas Gerais where there was only one root sample. 
State of Alagoas, from all root and stem samples from five cultivars from the sugarcane region of Pernambuco; from 5 root samples and 2 stem samples from 5 cultivars collected in Sáo Paulo State and from one cultivar collected from a farm in Minas Gerais (Table 1). Four to 20 strains were then chosen for further study.

Six experiments were performed to study the effects of various carbon sources and sugar and buffer concentrations on nitrogenase activity and $\mathrm{pH}$ changes and to study the effects of the initial $\mathrm{pH}$ on $\mathrm{N}_{2}$-dependent growth and nitrogenase activity. In all these experiments $5 \mathrm{ml}$ of semisolid LGI medium in $10 \mathrm{ml}$ serum vials was used as basic medium. For comparison type strains of Frateuria aurantia (ATCC 33424); Gluconobacter oxidans (ATCC 19357) and Acetobacter aceti (ATCC 15973), kindly provided by Dr J De Ley, were included in some experiments.

$\mathrm{C}_{2} \mathrm{H}_{2}$ reduction was estimated by closing the vials of semisolid medium with rubber stoppers and incubating under air with $10 \% \mathrm{C}_{2} \mathrm{H}_{2}$ for one hour (unless otherwise stated). $\mathrm{C}_{2} \mathrm{H}_{4}$ concentration was estimated using a Perkin Elmer F11 gas chromatograph fitted with a hydrogen flame ionization detector.

All biochemical tests for the characterization of the new bacterium were performed as recommended in Bergey's Manual of Systematic Bacteriology (1984) for the characterization of the genera Frateuria, Gluconobacter and Acetobacter.

\section{Results}

In diluted cane juice medium microbial growth was observed up to dilutions $10^{-7}$, occasionally $10^{-8}$, but $\mathrm{C}_{2} \mathrm{H}_{2}$ reduction was observed only up to dilutions $10^{-5}$ or $10^{-6}$, occasionally $10^{-7}$. Growth in LGI medium, or in acetic LGI medium and several modifications of it, was observed only at much lower dilutions. Nitrogenase positive vials with these $\mathrm{N}$-free media showed a thick yellow surface pellicle and the medium was decolourized. Most successful isolation was obtained however by transferring growth from diluted cane juice medium (light-coloured vials with whitish surface pellicles) into acetic LGI medium and subsequently streaking out on LGI or potato agar plates and incubating for 7 to 10 days. In some cases the new bacterium was also obtained from vials showing growth throughout the medium and gas production, but no other aerobic or microaerobic $\mathrm{N}_{2}$ fixing bacteria could be isolated. No attempts were made to isolate facultative anaerobic bacteria.

On isolation plates the only colony type which consistently showed nitrogenase activity when transferred into semisolid LGI or acetic LGI medium, were dark orange to red colonies on LGI plates. These could be minute $(<1 \mathrm{~mm})$ when close to colonies of other bacteria, or larger $(2-3 \mathrm{~mm}$, irregular) when in pure or almost pure culture. In semisolid LGI or acetic LGI media these colonies started growth after one to two days in a veil-like pellicle similar to that of azospirilla in semisolid malate medium, but with pronounced acid production. The pellicle soon concentrated on the surface and became dark yellow, growing thicker and assimilating the bromothymol blue from the medium which became colourless. These isolates in pure culture formed irregular smooth flat, initially small, white colonies which continued growing, becoming yellow, orange and finally almost red and $2-3 \mathrm{~mm}$ in diameter on LGI plates. The colonies became chocolate brown after 10 days on potato agar.

Preliminary attempts to isolate the new bacterium from roots and stems of sweet sorghum failed, but the characteristic growth pattern in semisolid LGI medium has been observed previously in Azospirillum amazonense counts with root samples of various other cereals.

The peculiar $\mathrm{pH}$ requirements were studied in more detail. In the study of the effect of the initial $\mathrm{pH}$ of semisolid LGI medium (acidified with $\mathrm{H}_{2} \mathrm{SO}_{4}$ ) after two days of incubation the organism showed some $\mathrm{N}_{2}$-dependent growth with nitrogenase activity at an initial pH of 3.8 to 5.8 (Fig. 1A). This initial $\mathrm{pH}$ however changed rapidly, dropping to a value of around 3.0, independent of the initial $\mathrm{pH}$ (Fig. 1B). Much faster and more acid-tolerant growth, with an optimum at $\mathrm{pH} 3.9$, was obtained when acetic acid was used to acidify the medium or when yeast extract was added (Fig. 1A). When $\mathrm{N}_{2}$-dependent growth, evaluated by $\mathrm{C}_{2} \mathrm{H}_{2}$ reduction, was estimated later $(72 \mathrm{~h})$ the optimum initial $\mathrm{pH}$ was 6.0 because the $\mathrm{pH}$ of the medium after $72 \mathrm{~h}$ had dropped further (Figs. 1A and $1 \mathrm{~B}$ ).

In a second experiment glucose $(2.5 \%)$ and sucrose $(10 \%)$ were contrasted at two buffer con- 


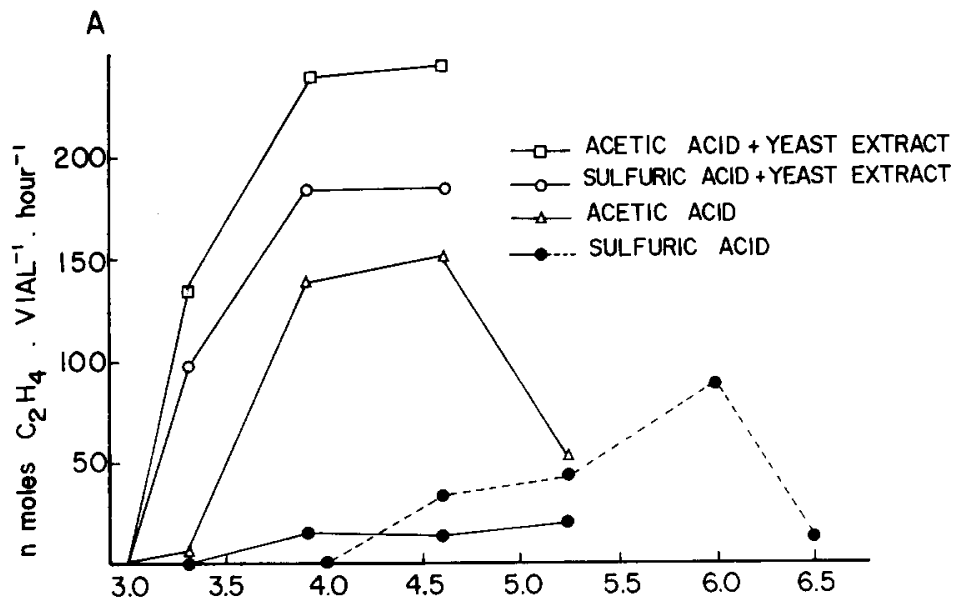

B

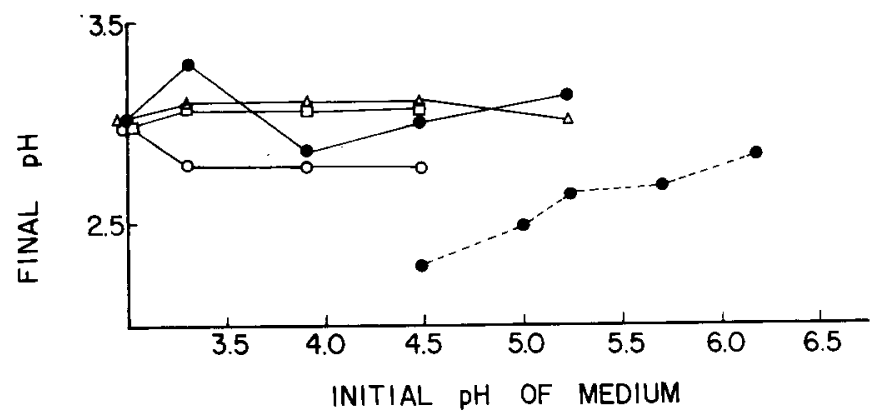

Fig. 1. Effect of the initial pH of the medium on the nitrogenase activity (Fig. 1A) and on the final pH (Fig. 1B) of the new bacterium. Semisolid LGI medium $\left(5 \mathrm{ml} \mathrm{vial}{ }^{-1}\right.$ ) acidified with either $\mathrm{H}_{2} \mathrm{SO}_{4}$ or with acetic acid, with or without $0.07 \%$ yeast extract, were inoculated with $0.1 \mathrm{ml}$ of $\log$ phase cultures and $\mathrm{C}_{2} \mathrm{H}_{2}$ reduction measured after $48 \mathrm{~h}$ under air after a $1 \mathrm{~h}$ incubation. For comparison results from a second experiment with LGI medium acidified with $\mathrm{H}_{2} \mathrm{SO}_{4}$, incubated for $72 \mathrm{~h}$, (broken lines) are included. Values are means of 4 strains, one vial each.

centrations (5.6 $\mathrm{m} M$ and $14.3 \mathrm{~m} M$ in phosphate) with an initial $\mathrm{pH}$ of 6.0 (Fig. 2) and the three acetic acid bacteria were included for comparison. No growth was observed in $\mathrm{N}$-free media with these three genera and no nitrogenase activity occurred even in cultures where $0.07 \%$ yeast extract had

Table 2. Analysis of variance of the results in Fig. 2B

\begin{tabular}{llcc}
\hline $\begin{array}{l}\text { Source of } \\
\text { variation }\end{array}$ & $\begin{array}{l}\text { Degrees of } \\
\text { freedom }\end{array}$ & \multicolumn{2}{c}{ Variance ratio $(\mathrm{F})^{\mathrm{a}}$} \\
\cline { 3 - 4 } & & $\mathrm{pH}$ & $\begin{array}{l}\text { Nitrogenase } \\
\text { activity }\end{array}$ \\
\hline Carbon source & 1 & 4.15 & $12.70^{* *}$ \\
Buffer conc. & 1 & $63.04^{* *}$ & $28.89^{* *}$ \\
Time & 3 & $34.20^{* *}$ & $20.91^{* *}$ \\
Carbon source & 3 & $1.80 \mathrm{~ns}$ & $2.94^{*}$ \\
$\quad \times$ Time $\times$ & & & \\
$\quad$ Buffer conc. & & & \\
Error & 45 & & \\
\hline
\end{tabular}

a Only data for significant effects and interactions shown. *, ** significantly different at $5 \%$ and $1 \%$ respectively.
Table 3. Effect of sucrose concentrations on nitrogenase activity (in moles $\mathrm{C}_{2} \mathrm{H}_{4} \cdot \mathrm{h}^{-1} \cdot 5 \mathrm{ml}$ culture ${ }^{-1}$ ) of the new bacterium in semisolid LGI medium ( $\mathrm{pH}$ 5.5). Data are means with their standard deviations of 20 strains in Exp. I and of 4 strains in Exp. II

Concentration $\quad$ Experiment $\mathrm{I}^{\mathrm{a}} \quad$ Experiment II
of sucrose ${ }^{b}$ $(\%)$

\begin{tabular}{rcc}
\hline 1 & $62 \pm 10$ & - \\
2 & $95 \pm 16$ & - \\
8 & $127 \pm 17$ & - \\
10 & $116 \pm 17$ & $31 \pm 1$ \\
15 & - & $15 \pm 7$ \\
20 & - & $12 \pm 4$ \\
25 & - & $7 \pm 2$ \\
30 & - & $14 \pm 4$ \\
\hline
\end{tabular}

a Acetylene reduction assayed after 3 days of incubation at $31 \mathrm{C}$ during 4.5 hour in exp. I and 1 hour in exp. II.

b Crystallized cane sugar was used. 

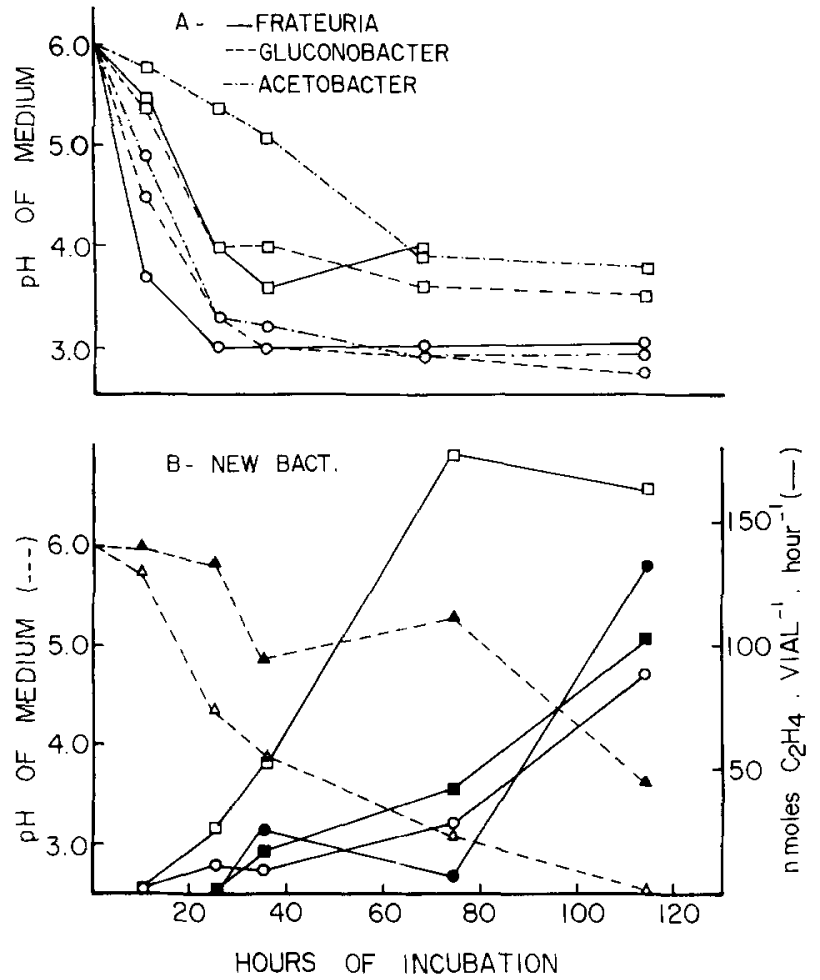

Fig. 2. Acid production from glucose or sucrose and nitrogenase acitivity of the new bacterium in comparison with three acetic acid bacteria. Acid production of Frateuria aurantia, Gluconobacter oxidans and Acetobacter aceti (Fig. 2A) and acid production and nitrogenase activity of the new bacterium (Fig. 2B) were followed in semisolid LGI medium $\left(5 \mathrm{ml} \mathrm{vial}^{-1}\right)$ with initial pH 6.0 at two buffer concentrations (open symbols 5.6 and closed symbols $14.3 \mathrm{mM}$ in phosphate respectively). For the three acetic acid bacteria the medium contained $0.07 \%$ yeast extract. Inoculation was with $0.1 \mathrm{ml}$ of $\log$ phase cultures and $\mathrm{C}_{2} \mathrm{H}_{2}$ reduction was measured under air after $1 \mathrm{~h}$ incubation. Different vials were used for each time interval and values are single observations of the acetic acid bacteria (Fig. 2A) and means of two replicate vials from two strains of the new bacterium (Fig. 2B). Square symbols are sucrose and round symbols glucose. Triangles represent means of sucrose and glucose for pH (Fig. 2B).

been added for growth. With glucose, acid production of these three genera was faster than that of the new bacterium but all levelled out at a $\mathrm{pH}$ between 2.8 and 3.0. Acid production from sucrose was less active, especially with Acetobacter (Fig. 2A). Nitrogenase activity of the new bacterium (grown without yeast extract) increased during 3 days while the $\mathrm{pH}$ dropped from 6.0 to 3.0 and continued at increasing rates during a further 2 days with the $\mathrm{pH}$ at 3.0 or below. Statistical analyses of the data from the new bacterium only (Table 2 ) indicate signi- ficant differences between the two sugars for nitrogenase activity and for $\mathrm{pH}$. With sucrose the higher buffer concentration significantly decreased nitrogenase activity, possibly because the $\mathrm{pH}$ remained higher (Fig. 2B).

In a third experiment the acidification of semisolid LGI medium with $1 \%$ mannitol, glycerol or ethanol was studied (Fig. 3). No acid production occurred with mannitol but there was a drop from pH 5.5 to 4.7 with glycerol. Acid production from ethanol was much faster and more pronounced and the $\mathrm{pH}$ dropped to 2.8 in $48 \mathrm{~h}$ but returned afterwards to almost the original pH (Fig. 3).

Requirement for high sugar concentrations was investigated in two additional experiments. $\mathrm{N}_{2}$ dependent growth and nitrogenase activity occurred between 1 and $30 \%$ cane sugar with an optimum between 10 and $15 \%$ (Table 3). Visual observations at various glucose concentrations $(0.1,0.2,0.5,1.0,5$, and $10 \%)$ showed optical $\mathrm{N}_{2}$-dependent growth with 5 and $10 \%$ glucose.

With such peculiar characteristics the new organism seemed to have no relationship to any known $\mathrm{N}_{2}$-fixing bacterium but rather resembled the acetic acid bacteria even though they never have been described as being able to fix $N_{2}$. All further characterization was therefore conducted according to the differential characteristics between the three known genera of acetic acid bacteria (Bergey's Manual of Systematic Bacteriology 1984) and in comparison with one type strain each of

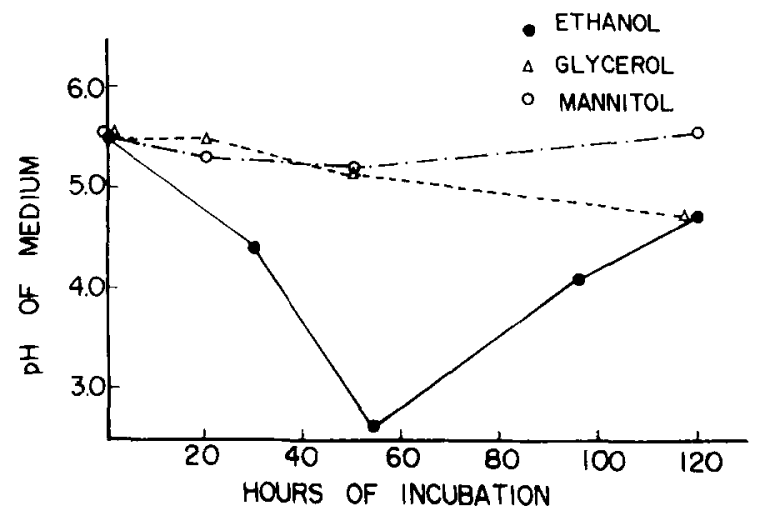

Fig. 3. Acid production and consumption from mannitol, glycerol and ethanol by the new bacterium. Vials of semisolid LGI medium ( $\left.5 \mathrm{ml} \mathrm{vial}^{-1}\right)$, without sugar, with initial $\mathrm{pH} 5.5$ and $1 \%$ mannitol, glycerol or ethanol were inoculated with $0.1 \mathrm{ml}$ of $\mathrm{log}$ phase cultures. Different vials were used for each time interval and the values are means of 4 strains, one vial each. 
Table 4. Comparison of the new bacterium with closely related genera of acetic acid bacteria as described by Swings $e t$ al. (1984), De Ley and Swings (1984) and De Ley et al. (1984)

\begin{tabular}{|c|c|c|c|c|}
\hline & New bacterium & Frateuria & Gluconobacter & Acetobacter \\
\hline \multicolumn{5}{|l|}{ Flagellar arrangement } \\
\hline polar & $-{ }^{a}$ & + & + & - \\
\hline peritrichous & - & - & - & + \\
\hline lateral & + & - & - & - \\
\hline Overoxidation of ethanol & + & - & - & + \\
\hline Overoxidation of glucose & + & - & - & - \\
\hline $\begin{array}{l}\text { Oxidation of DL-lactate } \\
\text { to } \mathrm{CO}_{2} \text { and } \mathrm{H}_{2} \mathrm{O}\end{array}$ & + & + & - & + \\
\hline $\begin{array}{l}\text { Dark brown colonies on } \\
\text { potato agar with } 10 \% \text { sugar }\end{array}$ & + & - & - & - \\
\hline $\begin{array}{l}\text { Brown water soluble pigment } \\
\text { on GYC agar }\end{array}$ & + & + & - & - \\
\hline $\begin{array}{l}\text { Growth factors required } \\
\text { in mannitol medium }\end{array}$ & - & - & + & $\mathrm{D}$ \\
\hline Formation of $\mathrm{H}_{2} \mathrm{~S}$ & + & + & - & - \\
\hline Growth with $30 \%$ glucose & + & + & - & - \\
\hline Growth on LGI plates & + & - & - & - \\
\hline $\begin{array}{l}\text { Growth in Frateur's Hoyer } \\
\text { mineral mannitol medium }\end{array}$ & + & + & - & - \\
\hline $\begin{array}{l}\text { Growth on } \mathrm{GYC}^{b} \text { agar pH } \\
\quad 4.5\end{array}$ & + & + & + & + \\
\hline $\mathbf{N}_{2}$ fixation & + & - & - & - \\
\hline $\mathrm{NO}_{3}$-reduction & - & - & - & - \\
\hline $\mathrm{N}_{2}$ fixation with $\mathrm{NO}_{3}^{-}$ & + & - & - & - \\
\hline Catalase & + & + & + & + \\
\hline Oxidase & - & - & - & - \\
\hline
\end{tabular}

a $(+)$ positive, $(-)$ negative, $\mathrm{D}$ differs between species.

b Glucose yeast extract $\mathrm{CaCO}_{3}$ agar plates (Micales et al., 1985).

Frateuria aurantia, Acetobacter aceti and Gluconobacter oxidans. The results are summarized in Table 4 and a more detailed comparison with Frateuria in Table 5.

In addition to the characteristics given in Tables 4 and 5 the following descriptive observations help to characterize the new bacterium in comparison with Frateuria, Gluconobacter and Acetobacter. The new bacterium when transferred into semisolid LGI or acetic LGI medium grew readily using $\mathrm{N}_{2}$ as the sole $\mathrm{N}$ source and cultures showed nitrogenase activity as evaluated by the $\mathrm{C}_{2} \mathrm{H}_{2}$ reduction method. Growth started in baloon or veil-like pellicles indicating aerotaxis and continued for more than one week when a thick surface pellicle formed which continued fixing $\mathrm{N}_{2}$ even after the $\mathrm{pH}$ had dropped to 2.5 or less. The aerotactic growth pattern was most pronounced in semisolid medium with $1 \%$ of ethanol and was also observed when $10 \mathrm{mM}$ of $\mathrm{NH}_{4} \mathrm{CL}$, which repressed nitrogenase, were added to the medium. Growth and nitro- genase activity were unaffected by $10 \mathrm{mMNO} \mathrm{NO}_{3}^{-}$. In liquid medium there was no $\mathrm{N}_{2}$-dependent growth or nitrogenase activity but there was turbidity with no surface pellicle in liquid medium with $\mathrm{NH}_{4}$ salts or yeast extract. No growth of Frateuria aurantia, Gluconobacter oxidans or Acetobacter aceti occurred in semisolid acetic LGI medium and there was no nitrogenase activity in this medium even when yeast extract was added as $\mathrm{N}$ source for growth (Fig. 2A).

Most remarkable were the colonies on yeast extract-ethanol $(1 \%) \mathrm{CaCO}_{3}$ agar and yeast extract glucose $(1 \%) \mathrm{CaCO}_{3}$ agar recommended by Micales et al. (1985), for the identification of acetic acid bacteria and to which bromothymol blue had been added ( $3 \mathrm{ml} 1 \% \mathrm{KOH}$ sol per $\mathrm{l}$ ). On the ethanol plates the new bacterium showed growth similar to Acetobacter, turning the medium first yellow and later (after 3 to 5 days) returning to blue with blue-green dry colonies while Acetobacter colonies were smooth and blue. The medium tur- 
ned blue with nacreous lustre due to precipitation of the dissolved $\mathrm{CaCO}_{3}$. Clear zones around isolated colonies later became white. The same plates inoculated with Frateuria aurantia or Gluconobacter oxidans remained yellow with yellow or light greenish growth. On glucose plates the new bacterium showed a growth pattern similar to that on ethanol but turned the medium dark brown after two weeks. Neither Acetobacter aceti nor the two other genera showed this kind of 'overoxidation' of glucose and plates even after 2 weeks remained yellow with yellow growth. On potato agar (with $10 \%$ sugar but not with $1 \%$ ) the new bacterium formed very characteristic dark-brown colonies, often with lighter colour margins, while Gluconobacter oxidans and Acetobacter aceti formed white colonies on potato agar and Frateuria did not grow on it. On LGI agar plates these three genera did not grow.

\section{Discussion}

Here we report the isolation of a new and entirely different $\mathrm{N}_{2}$-fixing bacterium which occurs in high numbers in sugarcane roots and stems, and shows optimal growth with $10 \%$ sugar and $\mathrm{pH}$ around 5.5 , precisely the conditions prevailing in sugarcane juice. This discovery will hopefully contribute to the elucidation of the mechanisms involved in diazotrophic associations in sugarcane and open up new pathways towards the partial replacement of nitrogenous fertilizers in a crop of great economic importance.

The new bacterium not only seems best adapted to the sugarcane environment, it is also an efficient, microaerobic $\mathrm{N}_{2}$-fixing bacterium which is able to fix $\mathrm{N}_{2}$ in the presence of nitrate, which may lead to the most important possibility of the complementation of nitrogen fixation with fertilizer applications. Among the $\mathrm{N}_{2}$-fixing bacteria known so far, only Azotobacter paspali, which specifically associates with Paspalum notatum (Dobereiner, 1966; Dobereiner and Day, 1975), and Bacillus azotofixans (Seldin et al., 1984) have been shown not to possess nitrate reductases.

According to Bergey's Manual of Systematic Bacteriology (1984) the new bacterium has to be identified within Section 4: Gram-Negative Aerobic Rods and Cocci. It seems very different from all
Table 5. Comparison of the use of carbon substrates by the new bacterium with that of Frateuria aurantia according to Swings $e t$ al. (1984) and own observations

\begin{tabular}{|c|c|c|}
\hline & New bacterium & F. aurantia \\
\hline \multicolumn{3}{|l|}{ Growth on $C$ sources: } \\
\hline sucrose, D-galactose & $++^{a}$ & +- \\
\hline D-arabinose, D-fructose & ++ & +- \\
\hline acetate lactate & +- & + \\
\hline malate & +- & +- \\
\hline ethanol $(1 \%)$ & + & +- \\
\hline mannitol, glycerol & + & +- \\
\hline i-inositol & + & +- \\
\hline yeast extract & ++ & + \\
\hline maltose & +- & + \\
\hline D-mannose & ++ & - \\
\hline \multicolumn{3}{|l|}{ Acid production from: } \\
\hline sucrose, galactose & + & + \\
\hline D-fructose & + & + \\
\hline glucose & ++ & ++ \\
\hline maltose & - & + \\
\hline D-mannose & ++ & + \\
\hline D-arabinose & ++ & + \\
\hline ethanol $(1 \%)$ & ++ & + \\
\hline i-inositol & - & + \\
\hline D-mannitol & - & - \\
\hline glycerol & + & - \\
\hline
\end{tabular}

other $\mathrm{N}_{2}$-fixing bacteria but in view of its capacity to oxidize ethanol to acetic acid, its extreme acid tolerance, and its preference for high sugar concentrations it seems most closely related to one genus of the Pseudomonadaceae (Frateuria) and to Acetobacteriaceae (Table 4). Media acidified with acetic acid to $\mathrm{pH} 4.5$ as in our acetic LGI medium have been suggested for the isolation and identification of acetic acid bacteria (Micales et al., 1985). The characteristic overoxidation of ethanol which is considered the main differential characteristic of the genus Acetobacter would place it into this genus. However, several other features of the new bacterium resemble Frateuria: the brown diffusible pigment produced from glucose in the presence of yeast extract; the lack of requirement for growth substances; the formation of $\mathrm{H}_{2} \mathrm{~S}$; and the growth in the presence of $30 \%$ glucose. Neither Frateuria nor any other members of the Acetobacteriaceae have been found to grow on $\mathrm{N}$-free media or to fix $\mathrm{N}_{2}$ in the presence of yeast extract. None of them has 1 to 3 lateral flagella. Furthermore there have been no reports of aerotactic growth patterns in 
semisolid media, of the "overoxidation" of glucose or the formation of dark-brown colonies on potato agar or dark-orange colonies on LGI plates containing bromothymol blue.

No determinations of $\% \mathrm{G}+\mathrm{C}$ or DNA/rRNA or DNA/DNA homology studies have as yet been performed with the new bacterium. In both rRNA superfamilies (sensu De Ley, 1978), superfamily IV which includes Acetobacteriaceae and II which includes Frateuria, there are $\mathbf{N}_{2}$-fixing bacteria (Azospirillum, Rhizobium, Xanthobacter and Beijerinckia in superfamily IV and Azotobacter and Azomonas in family II - De Smedt et al., 1980; De Vos, 1980; Swings et al., 1980). However, these $\mathrm{N}_{2}$ fixers have little similarity with the new bacterium except that they fix $\mathrm{N}_{2}$.

In view of the importance of this bacterium and the important differences which distinguish it from all possibly related bacteria, we propose a new genus and species for it which we name Saccharobacter nitrocaptans.

The preliminary description of this organism is as follows: Saccharobacter nitrocaptans gen. nov. sp. nov. (L.n. Saccharum sugar; L. bacterium) sp. nov. (L.n. nitrum; L.v. captura to put in accessible form); M.L. part adj. nitrocaptans dinitrogen fixing, straight rods about $0.7 \times 2 \mu \mathrm{m}$ rounded ends, gram negative, motile by 1 to 3 lateral flagella. Microaerobic dinitrogen fixers which grow on $\mathrm{N}_{2}$ as sole $\mathrm{N}$ source in semisolid media and after initial growth with starter nitrogen in liquid media. Grow well in liquid media with combined $\mathrm{N}$ sources. Nitrate is not reduced and there is $\mathrm{N}_{2}$ fixation at high nitrate concentrations $(10 \mathrm{mM})$. Possess a respiratory metabolism with oxygen as the terminal electron acceptor. Optimum growth temperature is around $30^{\circ} \mathrm{C}$ and optimum $\mathrm{pH}$ around 5.5. Do not grow at $\mathrm{pH} 7.0$ but do grow and fix $\mathrm{N}_{2}$ at $\mathrm{pH}$ below 3.0. Catalase positive and oxidase negative. $\mathrm{H}_{2} \mathrm{~S}$ is formed from cystein. Growth is poor on organic acids such as malate, succinate, acetate, citrate or lactate, but acetate and lactate are oxidized to $\mathrm{CO}_{2}$ and $\mathrm{H}_{2} \mathrm{O}$. High concentrations $(10 \%)$ of sucrose are the best carbon source for growth but glucose, fructose and galactose are also used. Growth and $\mathrm{N}_{2}$ fixation occur with $30 \%$ glucose or sucrose. Ethanol $(1 \%)$, mannitol and glycerol are also used for growth. Acid is produced from ethanol and some from glycerol. On GYC plates the acid produced from ethanol and glucose is further oxidized to $\mathrm{CO}_{2}$ and $\mathrm{H}_{2} \mathrm{O}$ (overoxidation) and $\mathrm{CaCO}_{3}$ is precipitated showing a nacreous lustre. The habitat is roots and stems of sugarcane.

\section{Addendum}

While in press, DNA/RNA TM values and DNA/DNA binding values obtained by $M$. Gillis (pers. comm.) showed the organism to be a new species of the genus Acetobacter. The proposed name has therefore to be changed to Acetobacter nitrocaptans.

\section{Acknowledgements}

Thomas Hurek and Barbara Reinhold (University of Hannover) first suggested using media based on sugarcane juice for the isolation of $\mathrm{N}_{2}$-fixing bacteria associated with sugarcane, during a $\mathrm{CNPq} /$ KFA exchange visit in our laboratory. Thanks are due to SS Urquiaga Caballero, FF Duque, MB Pereira and research workers of Planalsucar Experimental Station, Alagoas for collection of sugarcane roots, to Prof Maria Evangelina Ferreira Fonseca UFRJ for identification of the flagellar arrangement using transmission electron microscopy, to AO de Carvalho Dept. of Phytopathology, UFRRJ for the test for oxidase and to $V$ de Andrade for dedicated technical assistence.

Financial support for this research was provided by the US National Academy of Sciences/National Research Council by means of a grant from the US agency for International Development and also by COPERSUCAR.

\section{References}

Bergey's Manual of Systematic Bacteriology 1984 Eds. N R Krieg and J G Holt. Williams and Wilkins, Baltimore, USA. Vol I.

De Ley J 1978 Modern molecular methods in bacterial taxonomy: evaluation, application, prospects. In Proc. 4th Int. Conf. Plant Path. Bact. Angers. pp 347-357.

De Ley J and Swings J 1984 Genus II Gluconobacter 1935, 689 emend. mut. char. 1964, 100. In Bergey's Manual of Systematic Bacteriology. Eds. N R Krieg and J G Holt Vol I, pp 275-278 Williams and Wilkins, Baltimore, USA.

De Ley J, Swings J and Gassele F 1984 Genus I. Acetobacter beijerink 1898, 215. In Bergey's Manual of Systematic Bac- 
teriology. Eds. N R Krieg and J G Holt, Vol I, pp 270-274. Williams and Wilkins, Baltimore, USA.

De Smedt J, Baurens M, Tijtgat R and De Ley J 1980 Intra and inter genetic similarities of ribosomal ribonucleic acid cistrons of free-living nitrogen-fixing bacteria. Int. J. Syst. Bacteriol. 30, 106-122.

De Vos P 1980 Intragenic and intergenic similarities of ribosomal RNA cistrons of the genus Pseudomonas and the implications for taxonomy. Antonie van Leeuwenhoek 46, 96.

Dobereiner J 1961 Nitrogen fixing bacteria of the genus Beijerinckia Derx in the rhizosphere of sugarcane. Plant and Soil 15, 211-216.

Dobereiner J 1966 Azotobacter paspali sp. n., uma bacteria fixadora de nitrogênio na rizofera de Paspalum. Pesq. Agropec. Bras. 1, 357-365.

Dobereiner J 1980 Forage grasses and grain crops. In Methods for Evaluating Biological Nitrogen Fixation. Ed. F J Bergersen, pp 535-556. John Wiley and Sons, Chichester, UK.

Dobereiner $J$ and Alvahydo R 1959 Sôbre a influênciada canade-açucar na ocorrência de "Beijerinckia" no solo. II. Influência das diversas partes do vegetal. Rev. Bras. Biol. 19, 401412.

Dobereiner J and Day J M 1975 Nitrogen fixation in the rhizosphere of tropical grasses. In Nitrogen Fixation by Free-living Micro-organisms. IBP 6, Ed. W D P Stewart, pp 39-56. Cambridge University Press, Cambridge, UK.

Dobereiner J, Day J M and Dart P J 1972 Nitrogenase activity in the rhizosphere of sugarcane and some other grasses. Plant and Soil 37, 191-196.
Lima E, Boddey R M and Dobereiner J 1987 Quantification of biological nitrogen fixation associated with sugarcane using a 15-N aided nitrogen balance. Soil Biol. Biochem 19, 165-170.

Micales B K, Johnson J L and Claus G W 1985 Deoxyribonucleic acid homologues among organisms in the genus Gluconobacter. Int. J. Syst. Bacteriol. 35, 79-85.

Patriquin D G, Gracioli L A and Ruschel A P 1980 Nitrogenase activity of sugarcane propagated from stem cuttings in sterile vermiculite. Soil Biol. Biochem. 12, 413-417.

Rennie R J 1981 A single medium for the isolation of acetylene reducing (dinitrogen-fixing) bacteria from soils. Can. J. Microbiol. 27, 8-14

Rennie R J, Freitas J R de, Ruschel A P and Vose P B 1982 Isolation and identification of $\mathrm{N}_{2}$-fixing bacteria associated with sugarcane (Saccharum sp.). Can. J. Microbiol. 28, 462467.

Ruschel A P 1979 Associative $\mathrm{N}_{2}$-fixation by sugarcane. In Associative $\mathrm{N}_{2}$ Fixation. Eds. P B Vose and A P Ruschel, Vol I. pp 81-90. CRC Press, Boca Raton, USA.

Seldin L, Elsas J D van and Penido E G C 1984 Bacillus azotofixans sp. nov., a nitrogen-fixing species from Brazilian soils and grass roots. Int. J. Syst. Bacteriol. 34, 451-456.

Swings J, Gillis K, Kersters K, De Vos P, Gosselě F and De Ley J 1980 Frateuria, a new genus for "Acetobacter aurantius" Int. J. Syst. Bacteriol. 30, 547-556.

Swings J, De Ley J and Gillis M 1984 Genus III Frateuria 1984, 547. In Bergey's Manual of Systematic Bacteriology. Eds. N R Krieg and J G Holt, Vol I pp 210-213. Williams and Wilkinds, Baltimore, USA. 